ORIGINAL ARTICLE

\title{
Spatio-temporal variation in the structure of a deep water Posidonia oceanica meadow assessed using non-destructive techniques
}

\author{
Joseph Anthony Borg, Mark Alan Micallef \& Patrick Joseph Schembri \\ Department of Biology, University of Malta, Msida, Malta
}

Keywords

Deep water; lower infralittoral; Maltese

Islands; non-destructive sampling; Posidonia

oceanica; seagrass; underwater photography.

\section{Correspondence}

Joseph Anthony Borg, Department of Biology, University of Malta, Msida MSD06, Malta.

E-mail: joseph.a.borg@um.edu.mt

Accepted: 4 March 2006

doi:10.1111/j.1439-0485.2006.00085.x

\begin{abstract}
The Malta-Comino Channel (Maltese islands, central Mediterranean), supports extensive meadows of the seagrass Posidonia oceanica that in some places extend to a depth of around $43 \mathrm{~m}$, which is rare for this seagrass. To assess spatial and temporal variation in the state of the deeper parts of the P. oceanica meadow with time, data on the structural characteristics of the seagrass meadow at its lower bathymetric limit were collected during the summers of 2001, 2003 and 2004 from four stations (two stations within each of two sites) located at a similar depth, over a spatial extent of $500 \mathrm{~m}$. Shoot density was estimated in situ, while data on plant architecture (number of leaves, mean leaf length, and epiphyte load) were successfully obtained using an underwater photographic technique that was specifically designed to avoid destructive sampling of the seagrass. Results indicated that $P$. oceanica shoot density was lower than that recorded from the same meadow during a study undertaken in 1995; the observed decrease was attributed to the activities of an offshore aquaculture farm that operated during the period 1995-2000 in the vicinity of the meadow. ANOVA indicated significant spatial and temporal variations in meadow structural attributes at both sites during the 3-year study; for example, shoot density values increased overall with time at site A; a indication of potential recovery of the meadow following cessation of the aquaculture operations. Lower shoot density values recorded from site B (compared with site A) were attributed to higher epiphyte loads on the seagrass, relative to those at site A. The findings, which include new data on the structural characteristics of $P$. oceanica occurring at depths $>40 \mathrm{~m}$, are discussed with reference to the use of the nondestructive photographic technique to monitor the state of health of deep water seagrass meadows.
\end{abstract}

\section{Problem}

Seagrasses form extensive meadows in coastal waters worldwide, but because of their requirements for higher levels of light compared with other marine photoautotrophs, they are generally restricted to shallow waters (Green \& Short 2003), typically $<50 \mathrm{~m}$ deep (Den Hartog \& Phillips 2001). The occurrence of seagrasses at depths $>40 \mathrm{~m}$ has occasionally been reported (e.g. Lipkin 1979;
Lee Long et al. 1996), however, such records are very infrequent, while data on the structural characteristics of deep water seagrass meadows are lacking.

The endemic Mediterranean seagrass Posidonia oceanica (L.) Delile forms continuous meadows that extend to a maximum water depth of around $45 \mathrm{~m}$ (Meinesz et al. 1988; Procaccini et al. 2003), however, the occurrence of $P$. oceanica at the lower end of this depth range is considered unusual. Furthermore, most records of the seagrass 
from depths exceeding $40 \mathrm{~m}$ mainly refer to isolated shoots that do not form a typical meadow (e.g. Meinesz et al. 1988; Boudouresque et al. 1990; but see also Augier \& Boudouresque 1979). In 1995, Borg \& Schembri reported the occurrence of a $P$. oceanica meadow that extended to a depth of 43-44 m in the Malta-Comino Channel (Fig. 1a and b); this deep water meadow had a shoot density of $125-155$ shoots $\mathrm{m}^{-2}$; the mean number of leaves per shoot was 4.2, and the mean leaf length (based on intermediate and adult leaves) was $14.4 \mathrm{~cm}$ (Borg \& Schembri 1995a). However, these data were based on shoots collected from a single station. On the other hand, given the low shoot density of this meadow, and that $P$. oceanica is a protected species, it was not desirable to use standard shoot collection techniques at multiple stations in a more detailed study of the plant architectural characteristics, since this would probably have had an adverse impact on the seagrass. The need was felt, therefore, to develop a non-destructive technique to monitor the state of this deep water $P$. oceanica meadow over time, particularly in view of its occurrence at such extreme depths, and the vulnerability of such deep- growing beds to regression caused by alterations in the marine environment resulting from anthropogenic activities (Marbà et al. 1996), as has occurred in various parts of the Mediterranean (Procaccini et al. 2003). Development and use of such a technique for the deep water seagrass meadow would also be appropriate given that the geographical location of the lower limit of $P$. oceanica meadows is often used to monitor the state of health of the seagrass and to quantify regression and loss of the habitat (see reviews by Procaccini et al. 2003; Buia et al. 2004).

The present study was primarily aimed at designing a non-destructive technique to collect data on widely used meadow structural attributes (shoot density, mean number of leaves and mean leaf length per shoot, and epiphyte load) that may be applied to the Maltese deep water $P$. oceanica meadow at its lower limit $(41-43 \mathrm{~m})$. Furthermore, since offshore fish-farming activities (sea bream culture) were carried out in the vicinity of the deep water P. oceanica meadow between 1995 and 2000 (during which period no monitoring of the deep water $P$. oceanica meadow was undertaken), data from this

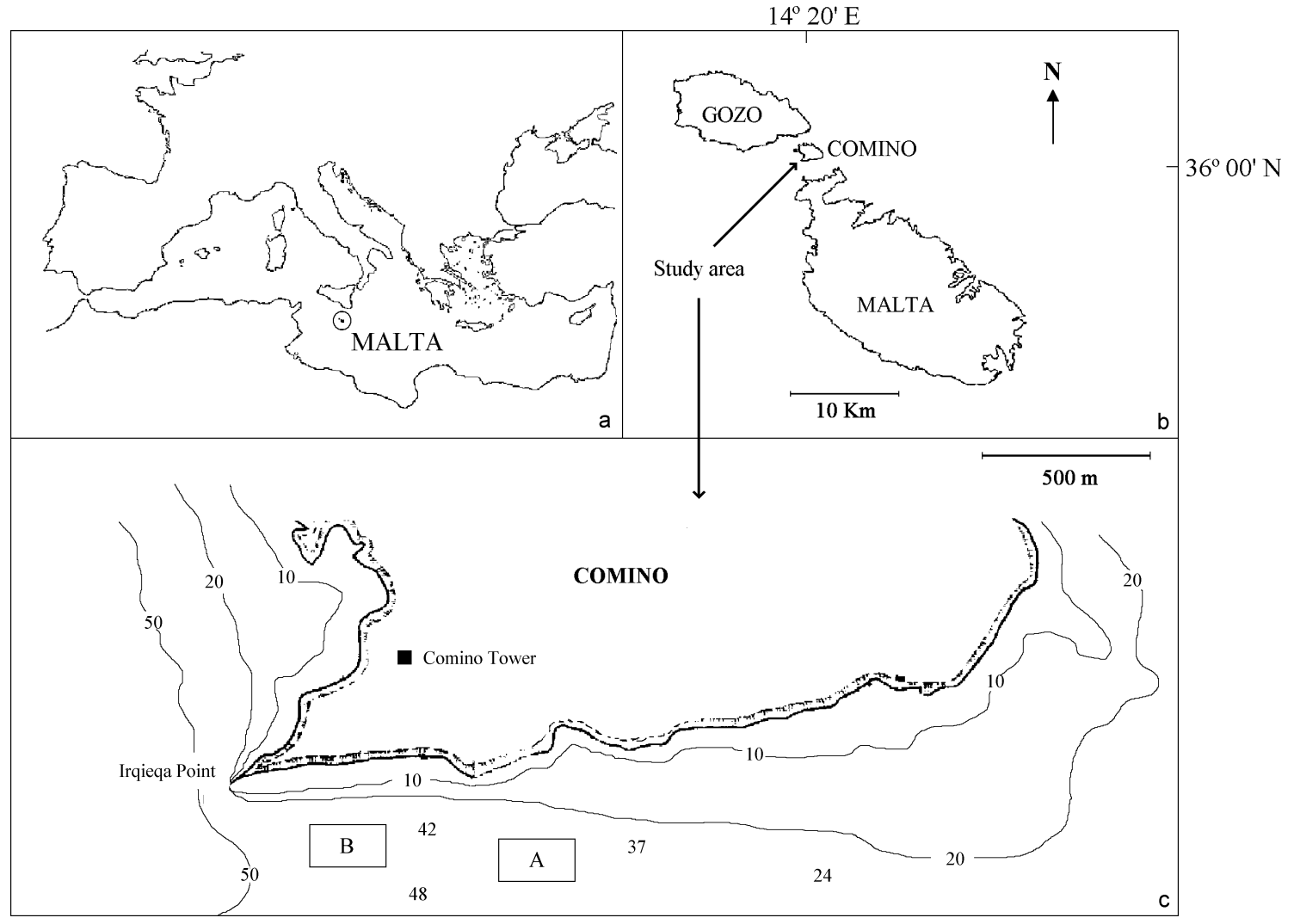

Fig. 1. Maps showing the location of: (a) the Maltese Islands in the Mediterranean; (b) the study area; and (c) the two sites: $A$ (centred on $36^{\circ} 00.190^{\prime} \mathrm{N} / 14^{\circ} 20.127^{\prime} \mathrm{E}$ ) and $\mathrm{B}$ (centred on $36^{\circ} 00.220^{\prime} \mathrm{N} / 14^{\circ} 19.760^{\prime} \mathrm{E}$ ). Site $\mathrm{A}$ is located close to where an offshore fish farm was present between 1995 and 2000 . 
study may help establish whether the aquaculture activities had affected the seagrass adversely [see Holmer et al. (2003) for a review of the adverse effects of aquaculture activities on seagrass meadows].

\section{Material and Methods}

The study area is located off the southwestern tip of the island of Comino in the Malta-Comino Channel (Fig. 1b and c), which supports some of the most extensive and healthy meadows of $P$. oceanica in the Maltese Islands (Borg \& Schembri 1995a). The deep water P. oceanica meadow in the study area occurs on a coarse sandy bottom off the southern shore of Comino (see Fig. 1c) and has a spatial extent of around $700 \mathrm{~m}$ (measured West-East). Very sparse stands of the alien alga Caulerpa racemosa (recorded for the first time from Malta in 1997; authors, unpublished data) occurred in places amongst the seagrass shoots. However, no dense stands of the alga were noted in any part of the meadow, and it was deemed unlikely that the alga was having any adverse impact on the seagrass. To collect data on the deep water meadow, two sites (A and B) separated from each other by a distance of about $500 \mathrm{~m}$, and located at the eastern and western extremes of the meadow were chosen. The inclusion of additional sampling sites in the design was not possible since the seagrass meadow did not extend further west beyond 'Irqieqa Point', while it occurred in shallower waters $(<40 \mathrm{~m})$ east of site A (Fig. 1c). The aforementioned aquaculture installation was located adjacent to Site A (Fig. 1c). Two sampling stations, separated from each other by a distance of about $100 \mathrm{~m}$, were chosen within each of sites $A$ and $B$, such that the sampling design incorporated a total of four sampling locations. Preliminary dives indicated that $P$. oceanica was present in the $41-43 \mathrm{~m}$ depth range at all four stations. Although the four sampling stations were located at the lower end of the $P$. oceanica meadow, they were distant from its boundaries, and seagrass shoots were present at least to a distance of $20-25 \mathrm{~m}$ from the position of each station. In the field, sampling stations were located using a Global Positioning System (GPS) set, which enabled accurate relocation of the same station during subsequent site visits.

Shoot density estimates were made at each station by counting the number of shoots enclosed in five $35 \times 35 \mathrm{~cm}$ replicate quadrats (Buia et al. 2004). To measure seagrass architectural characteristics, photographs were taken of five individual shoots selected at random at each of the four sampling stations using a Nikonos $\mathrm{V}$ underwater camera equipped with a standard $35 \mathrm{~mm}$ lens. A greater number of shoots are usually taken for phenological studies of $P$. oceanica, however, since we were using standard SCUBA techniques and given the relatively great depths in the study area, the amount of available 'bottom' time was limited; under these circumstances, five replicates were considered adequate. Before taking each photograph, a plastic slate measuring $30 \times 40 \mathrm{~cm}$ with a scale graduated in centimetres was placed behind the seagrass shoot. Two $10 \mathrm{~cm}$ long flat bars attached to the lower edge of the slate held the latter in place when inserted into the soft sediment of the bottom (Fig. 2). Sampling was made in the summers of 2001, 2003 and 2004; no data were collected in 2002.

The total number of adult and intermediate leaves per shoot were counted from the photographs to obtain mean estimates. The photographs were then scanned at $300 \mathrm{dpi}$ on a flatbed scanner and the resulting digital images were analysed using the length and area measurement tools of UTHSCSA ImageTool v3.0 (Department of Dental Diagnostic Science, University of Texas Health Science Center, San Antonio, TX, USA) to obtain estimates of leaf length and leaf width per shoot. The same technique was used to obtain estimates of shoot epiphyte coverage, and the results were expressed as percentage coverage of epiphytes. Only the upper leaf surface was considered in the measurements. Where parts of the upper leaf surface were not visible in the photographs, the leaf width was taken as being equal to the mean leaf width for that particular leaf as estimated from three measurements along the leaf.

To overcome the difficulty resulting from instances where coverage of epiphytes exceeded the total surface area of the shoot, the index $\mathrm{x} / \mathrm{x}+\mathrm{y}$ was used, where $\mathrm{x}=$ coverage of epiphytes and $y=$ total (upper) leaf surface area of the shoot. A degree of error was unavoidably introduced in cases where parts of leaves were bent and their upper surface and attached epiphytes were not visible in the photograph. Because of this, estimates of epiphyte coverage were considered semi-quantitative and preliminary.

Three-factor ANOVA tests (with $\alpha$ set at 0.05) were carried out on values of the $P$. oceanica structural attributes using a model in which 'time' (three levels) was a fixed factor, while 'site' (two levels) and 'station' (two levels) were random factors. Prior to analyses, data were tested for homogeneity of variances using Cochran's test and, where necessary, appropriate transformations were applied (Underwood 1997). Analyses were carried out using the PC software package GMAV5 developed at the University of Sydney, Australia. Where the ANOVA indicated significant differences, the source of difference was identified using Student-Neuman-Keuls (SNK) tests.

\section{Results}

Fieldwork confirmed the presence of the deep water $P$. oceanica meadow at site A, close to where the offshore 
Fig. 2. Photograph of Posidonia oceanica shoots taken at a depth of $42 \mathrm{~m}$ at site $\mathrm{A}$. The white slate with scale was placed directly behind a seagrass shoot and used to obtain estimates of seagrass architectural attributes.

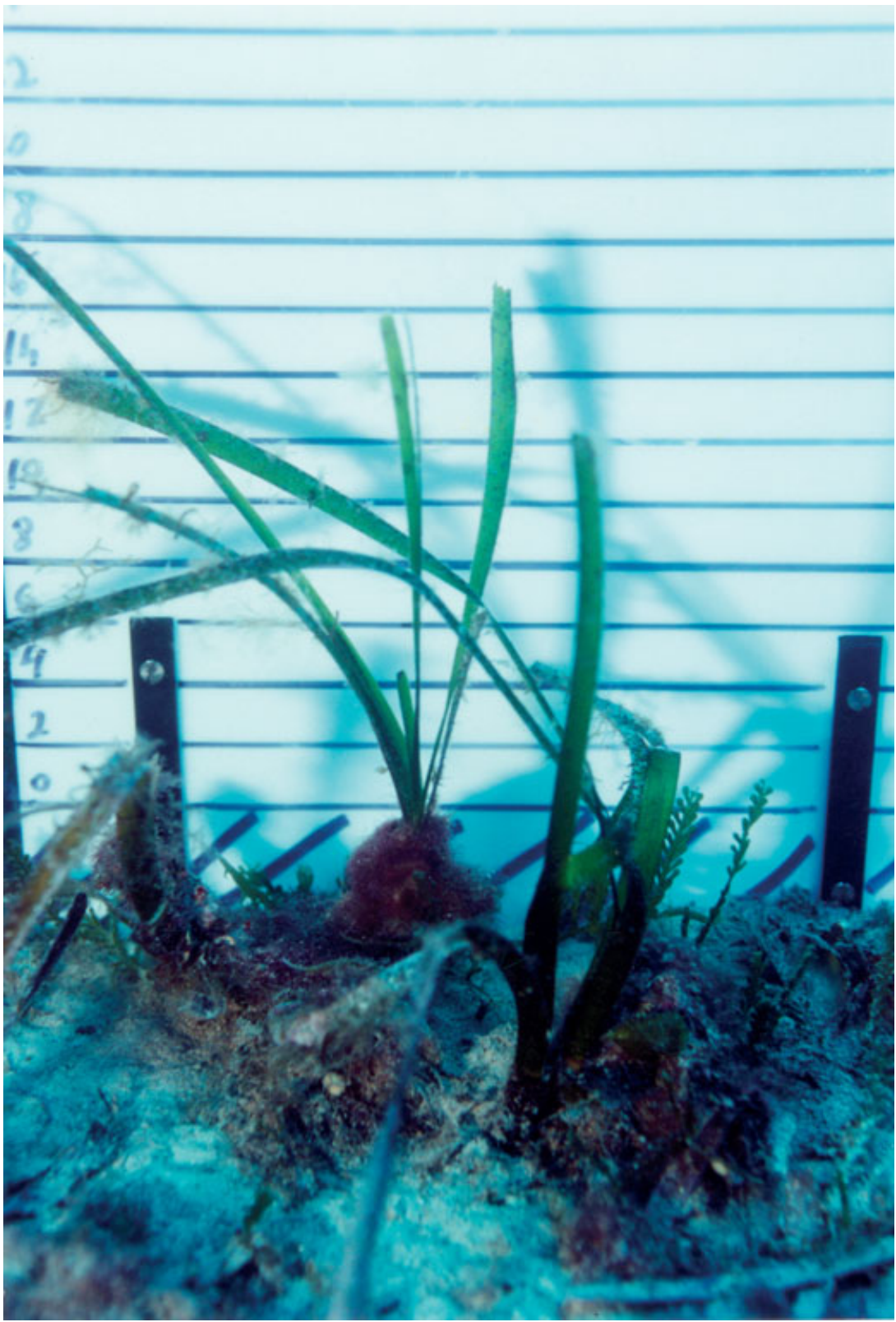

temporal variation in structural attributes of the deep water P. oceanica meadow between the two sites (A and B). At the smaller spatial level ('stations within site'), significant differences were only detected for mean leaf length per shoot at site $B$.

Mean shoot density for the four stations over the whole sampling period varied between 23 and 108 shoots $\cdot \mathrm{m}^{-2}$ (Fig. 3a). ANOVA indicated significant differences $(\mathrm{P}<0.05)$ in shoot density for the factor 'site' and a significant interaction 'time $\times$ site' $(\mathrm{P}<0.01)$ (Table 1$)$. The highest values were recorded in 2003 and 2004 from stations located within site A, which in turn had significantly higher shoot densities $(\mathrm{SNK} ; \mathrm{P}<0.01)$ than those 


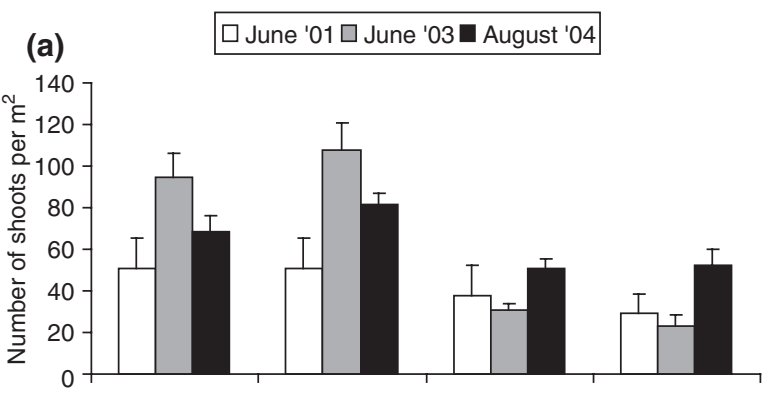

(b)

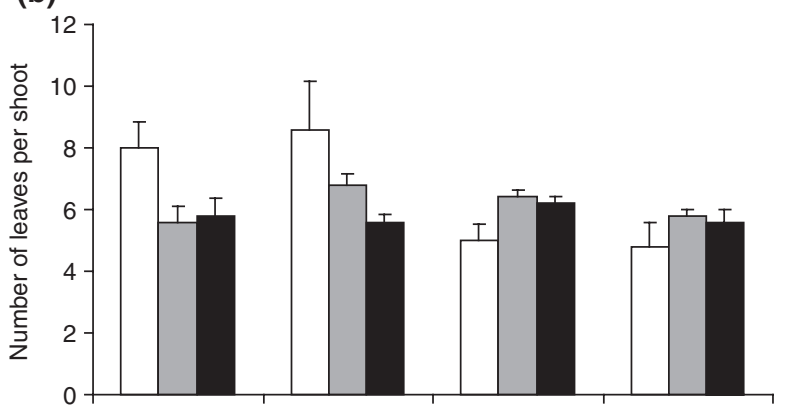

(c)

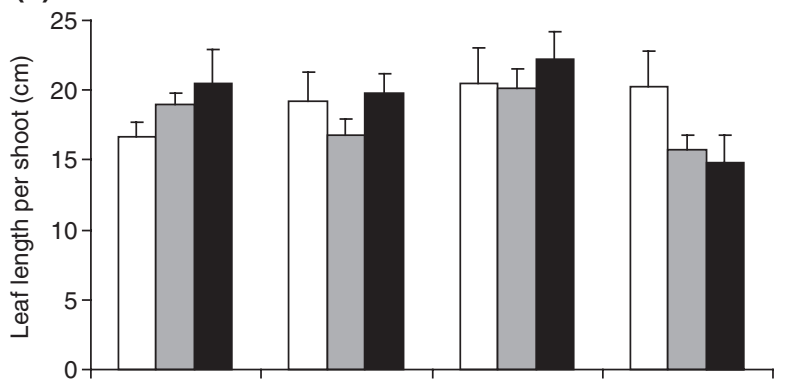

(d)

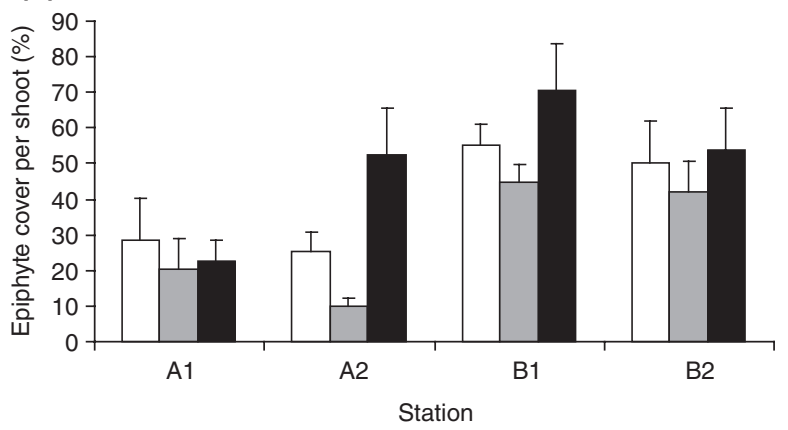

Fig. 3. Mean $( \pm S E)$ shoot density $\cdot m^{-2}(a)$, number of leaves per shoot (b), leaf length per shoot (c), and percentage epiphyte cover per shoot (d), recorded from the four sampling stations: A1 and A2 were located within site A; B1 and B2 were located within site B (see Fig. 1c).

recorded from the same stations in 2001 (Fig. 3a). ANOVA also indicated that shoot density was significantly lower overall at site B compared with site A (SNK; $\mathrm{P}<0.05)$.
The mean number of leaves per shoot varied between 4.8 and 8.6. The highest values were recorded from site A in 2001, while the lowest values were recorded from site $\mathrm{B}$ in the same year (2001) (Fig. 3b). ANOVA indicated a significant interaction 'time $\times$ site' $(\mathrm{P}<0.01)$ (Table 1$)$. The mean leaf length per shoot varied between 14.9 and $22.2 \mathrm{~cm}$, however, there was no apparent pattern of differences between the four stations over the study period (Fig. 3c). ANOVA indicated a significant difference for the term 'station (site)' $(\mathrm{P}<0.05)$, thereby showing that mean leaf length per shoot differed significantly at the 'station within site' level (Table 2), which was attributed to significant differences between the two stations located within site B (SNK; P < 005).

Values of percentage epiphyte cover were overall higher at site $\mathrm{B}$ compared with site $\mathrm{A}$; the highest values were recorded from stations $\mathrm{B} 1$ and $\mathrm{B} 2$, and from station $\mathrm{A} 2$, in 2004 (Fig. 3d). ANOVA indicated significant differences for the factors 'time' $(\mathrm{P}<0.01)$ and 'site' $(\mathrm{P}<0.05)$ (Table 2). These differences were attributed to an overall significantly higher shoot epiphyte load recorded from site B compared with site A (SNK; P < 0.05), and to significant differences in this attribute between the three times of sampling $(2003<2001<2004$; SNK: $\mathrm{P}<0.05)$.

\section{Discussion}

Non-destructive underwater photographic techniques have rarely been used to collect quantitative data on seagrass meadow characteristics, however, one such study describes derivation and use of an epiphyte photo-index (EPI) for assessing epiphyte loading on Halodule wrightii (Miller-Myers \& Virnstein 2000), while non-destructive underwater photography was used by Peirano et al. (2000) to study fruiting of P. oceanica. Understandably, the use of such techniques to study shoot morphological attributes of large seagrasses (such as $P$. oceanica) has severe practical limitations, since it is not possible to include a whole shoot in a single close-up photograph. However, the present study showed that such a technique can be used successfully to obtain quantitative data on deep water $(>35 \mathrm{~m})$ P. oceanica beds, since the constituent shoots tend to have relatively short leaf lengths (<50 cm long; e.g. Gobert et al. 2003). By analogy, such techniques can also be used to study and monitor the plant architecture of relatively small-sized seagrasses, particularly in cases where the meadows are sparse and where destructive sampling may negatively impact the seagrass habitat. The photographic technique used in the present study can be improved further, for example, by standardising photographic images against data collected from the field to develop an index for a specific seagrass 
Table 1. Summary of ANOVA results for Posidonia oceanica shoot density and number of leaves. Transformation of data, where applied, is indicated.
Table 2. Summary of ANOVA results for Posidonia oceanica leaf length and percentage epiphyte cover.

\begin{tabular}{|c|c|c|c|c|c|c|c|}
\hline \multirow[b]{2}{*}{ source of variation } & \multirow[b]{2}{*}{ df } & \multicolumn{3}{|c|}{$\begin{array}{l}\text { shoot density (per quadrat) } \\
(n=5)\end{array}$} & \multicolumn{3}{|c|}{$\begin{array}{l}\text { number of leaves (per shoot) } \\
(n=5)^{a}\end{array}$} \\
\hline & & mean square & $\mathrm{F}$ & $P$ & mean square & $\mathrm{F}$ & $P$ \\
\hline time & 2 & 46.867 & 0.64 & n.s. & 0.025 & 0.0500 & n.s. \\
\hline site & 1 & 331.350 & 58.99 & * & 0.402 & 7.270 & n.s. \\
\hline station (site) & 2 & 5.617 & 1.40 & n.s. & 0.055 & 1.170 & n.s. \\
\hline time $\times$ site & 2 & 73.400 & 44.04 & $* *$ & 0.500 & 28.990 & $* *$ \\
\hline time $\times$ station (site) & 4 & 1.667 & 0.41 & n.s. & 0.017 & 0.360 & n.s. \\
\hline residual & 48 & 4.017 & & & 0.047 & & \\
\hline
\end{tabular}

n.s., not significant

${ }^{a}$ Data transformed $[\ln (\mathrm{x})]$

${ }^{*} \mathrm{P}<0.05 ;{ }^{* * P}<0.01$

\begin{tabular}{|c|c|c|c|c|c|c|c|}
\hline \multirow[b]{2}{*}{ source of variation } & \multirow[b]{2}{*}{ df } & \multicolumn{3}{|c|}{ leaf length $(\mathrm{cm})(\mathrm{n}=5)$} & \multicolumn{3}{|c|}{ epiphyte cover (\%) ( $n=5)$} \\
\hline & & mean square & $F$ & $P$ & mean square & $\mathrm{F}$ & $P$ \\
\hline time & 2 & 12.578 & 0.61 & n.s. & 2117.562 & 113.22 & ** \\
\hline site & 1 & 1.286 & 0.02 & n.s. & 10336.908 & 29.49 & * \\
\hline station (site) & 2 & 61.062 & 3.88 & * & 350.459 & 0.82 & n.s. \\
\hline time $\times$ site & 2 & 20.533 & 0.89 & n.s. & 18.702 & 0.03 & n.s. \\
\hline time $\times$ station (site) & 4 & 23.076 & 1.46 & n.s. & 647.148 & 1.51 & n.s. \\
\hline residual & 48 & 15.758 & & & 429.984 & & \\
\hline
\end{tabular}

n.s., not significant.

${ }^{*} \mathrm{P}<0.05 ;{ }^{* * P}<0.01$ bed at a given depth (see Miller-Myers \& Virnstein 2000), and using macro photography to obtain better estimates of shoot epiphytic loading.

In the study area, the deep water $P$. oceanica meadow was characterised by shoot density and leaf length values that were, overall, lower than those typically recorded for the same seagrass from shallower waters $(5-30 \mathrm{~m})$ in the Maltese Islands (Drew \& Jupp 1976; Borg \& Schembri 1995b). On the other hand, values of mean number of leaves per shoot were not very different from those recorded for local meadows of the same seagrass in shallower waters (5-30 m) (Drew \& Jupp 1976; Borg \& Schembri 1995b). It therefore appears that the largest differences in structural characteristics between the deep water $(41-43 \mathrm{~m}) P$. oceanica meadow from the study area and meadows located at lesser depths concern shoot density and leaf length. This is consistent with the general pattern of a decrease in values of these two seagrass architectural attributes with water depth (e.g. Buia et al. 1989; Gobert et al. 2003). Published data on the meadow structural characteristics of $P$. oceanica from waters deeper than about $35 \mathrm{~m}$ are lacking, and as far as we are aware, the present study is the first to provide such data from depths of 41-43 m, replicated in space and time.

Our results confirmed the presence of $P$. oceanica at distances $>30 \mathrm{~m}$ from the area previously occupied by an offshore fish farm, but seagrass originally present under the cages, and within a $30 \mathrm{~m}$ wide band around them, had been decimated. Furthermore, shoot density values recorded from the study area were, overall, lower than those recorded by Borg \& Schembri (1995a) for the same meadow prior to initiation of the fish farming activities $\left(50-108\right.$ shoots $\cdot \mathrm{m}^{-2}$ recorded from the present study versus $125-155$ shoots $\mathrm{m}^{-2}$ recorded in 1995). Shading caused by the fish cages, together with alteration of the physico-chemical characteristics of the water column in the vicinity of offshore fish farms are known to adversely affect $P$. oceanica meadows (see review by Holmer et al. 2003). For example, for $P$. oceanica located close to an offshore fish farm in shallow waters (10-12 m) at Mistra Bay, Malta, changes in meadow structural characteristics were recorded at distances of up to $200 \mathrm{~m}$ from the cages (Dimech et al. 2002). One would expect that such adverse effects would be even more pronounced for deep water seagrass meadows, given that the plants are surviving close to the 'compensation depth', i.e. the depth at which sufficient light is present for sustaining plant growth (Bay 1984; Duarte 1991). Extirpation of the seagrass in the area previously occupied by the offshore cages and in their immediate vicinity may have been the result of the combined effect of shading by the fish cages and enrichment of the sediment and water column by waste from the 
farm, as has been reported from other parts of the Mediterranean (Holmer et al. 2003). At distances greater than $30 \mathrm{~m}$ from the farm, the seagrass would have been outside the shadow of the cages, while the strong water currents that prevail in the Malta-Comino Channel (JAB, personal observation) would have dissipated fish waste products and uneaten food away from the locality.

ANOVA indicated a significant increase in shoot density with time at site A since cessation of the fish farm operations, showing recovery of the seagrass meadow at that site. Unexpectedly however, seagrass shoot density at site B was significantly lower (ANOVA) than that at site $\mathrm{A}$, and remained so throughout the whole study period. ANOVA also indicated a significantly higher shoot epiphyte load at site B. The adverse effects of an excessive epiphyte cover on $P$. oceanica, including death of the plant and a subsequent reduction in meadow shoot density values, has been demonstrated (e.g. Pergent-Martini et al. 1995). Therefore, we suggest that the proximate cause of the significantly lower shoot density values at site $B$ is the high epiphyte loads on the seagrass shoots there, which attenuate the amount of photosynthetically active radiation (PAR) reaching the photosynthetic tissues of the leaves (e.g. Silberstein et al. 1986). Where light conditions are already marginal, such as at the lower depth limit of the seagrass, prolonged reduction in PAR levels may result in a severe limitation of growth, and possibly, in death of the plants due to a variety of effects triggered by altered gas and nutrient exchange at the leaf surface (Sand-Jensen 1977; Hemminga 1998). In turn, the high epiphyte loads at site B may have resulted from nutrient enrichment of the water column, but the source has not been identified and further studies are required. The possibility that the observed spatio-temporal differences in shoot density was related to variation in the physicochemical characteristics of the sediment was ruled out, given that no significant differences (ANOVA) in mean sediment grain size, and organic carbon and organic nitrogen content of the sediment were detected in space and time (authors, unpublished data).

The lower limit of a seagrass meadow is an important indicator of the state of health of the habitat (Buia et al. 2004). Changes in environmental quality resulting from anthropogenic activities, such as those caused by nutrient loading of the water column, are expected to result in changes in the structural characteristics at the lower limit of a seagrass meadow. The present study showed that non-destructive techniques, such as underwater photography, can be used to assess the structural characteristics of deep water $P$. oceanica meadows, and to monitor their state of health, while this and similar methods can be extended to other marine phanerogams, thereby contributing to the conservation of seagrass habitats.

\section{Summary}

A non-destructive underwater photographic technique was designed and used successfully to obtain data on the structural characteristics (number of leaves, mean leaf length, and epiphyte load) of a Maltese deep water (41-43 m) P. oceanica meadow in the Malta-Comino Channel. Data were collected from two stations within each of two sites (A and B) in the summers of 2001, 2003 and 2004. Results of three-factor ANOVA indicated significant spatial and temporal variation in $P$. oceanica meadow structure. Values of shoot density at the two sampling sites were, overall, lower than those recorded from the same meadow in 1995; the observed differences were attributed to probable adverse effects resulting from fish farming activities carried out in the vicinity of the meadow during the period 1995-2000. However, ANOVA also indicated a significant increase in shoot density at one of the sites (site A - located closest to the original fish farm site) with time, thereby showing recovery of the seagrass meadow at this site. On the other hand, ANOVA indicated that P. oceanica shoot density at site B was significantly lower than that at site A. The reduced shoot density at site B was attributed to a significantly higher shoot epiphyte load there, which was affecting the deep water $P$. oceanica meadow adversely.

\section{Acknowledgements}

This paper benefited from the suggestions of two anonymous referees. Financial assistance for the present work was provided by Azzopardi Fisheries (Malta), while the Malta Environment and Planning Authority entrusted us with the study. We thank both entities for permission to use the data generated during the study. This work is dedicated to the memory of Lucia Mazzella.

\section{References}

Augier H., Boudouresque C.F. (1979) Premières observations sur l'herbier de Posidonies et le détritique cotier de l'ile du Levant (Méditerranée, France), a l'aide du sous-marin Griffon de la Marine Nationale. Travaux Scientifiques $d u$ Parc National du Port-Cros, 5, 141-153.

Bay D. (1984) A field study of the growth dynamics and productivity of Posidonia oceanica (L.) Delile in Calvi, Corsica. Aquatic Botany, 20, 43-64.

Borg J.A., Schembri P.J. (1995a) The state of Posidonia oceanica (L.) Delile meadows in the Maltese Islands (Central Mediterranean). Rapports et Proces-Verbaux des Réunions Commission International pour l'Exploration Scientifique de la Mer Méditerranée, 34, 123. 
Borg J.A., Schembri P.J. (1995b) Preliminary data on bathymetric and temporal changes in the morphology of a Maltese Posidonia oceanica (L.) Delile meadow. Rapports et Proces-Verbaux des Réunions Commission International pour l'Exploration Scientifique de la Mer Méditerranée, 34, 20.

Boudouresque C.F., Bianconi C.H., Meinesz A. (1990) Live Posidonia oceanica in a corraligenous algal bank at Sulana Bay, Corsica. Rapports et Proces-Verbaux des Réunions Commission International pour l'Exploration Scientifique de la Mer Méditerranée, 32, 11-12.

Buia M.C., Cormaci M., Furnari G., Mazella L. (1989) Posidonia oceanica off Capo Passero (Sicily, Italy): leaf phenology and leaf algal epiphytic community. In: Boudouresque C.F., Meinesz A., Fresi E., Garvez V. (Eds), 2nd International Workshop on Posidonia Beds 2. Marseilles, France, 127-143.

Buia M.C., Gambi M.C., Dappiano M. (2004) Seagrass systems. In: Gambi M.C., Dappiano M. (Eds), Mediterranean Marine Benthos: A Manual of Methods for its Sampling and Study. Biologia Marina Mediterranea, 11 (Suppl. 1), 133-183.

Den Hartog C., Phillips R.C. (2001) Common structures and properties of seagrass beds fringing the coasts of the world. In: Reise K. (Ed.), Ecological Comparisons of Sedimentary Shores. Springer-Verlag, Berlin, Heidelberg: 195-212.

Dimech M., Borg J.A., Schembri P.J. (2002) Changes in the structure of a Posidonia oceanica meadow and in the diversity of associated decapods, mollusc and echinoderm assemblages resulting from inputs of waste from a marine fish farm (Malta, Central Mediterranean). Bulletin of Marine Science, 71, 1309-1321.

Drew E.A., Jupp B.P. (1976) Some aspects of the growth of Posidonia oceanica in Malta. In: Drew E.A., Lithgoe J.N., Woods J.D. (Eds), Underwater Research. Academic Press, London: 357-369.

Duarte C.M. (1991) Seagrass depth limits. Aquatic Botany, 40, 363-377.

Gobert S., Kyramarios M., Lepoint G., Pergent-Martini C., Bouquegneau J.M. (2003) Variations at different spatial scales of Posidonia oceanica (L.) Delile beds; effects on the physico-chemical parameters of the sediment. Oceanologica Acta, 26, 199-207.

Green E.P., Short F.T. (2003) World Atlas of Seagrasses. UNEP World Conservation Monitoring Centre. University of California Press, Berkeley, USA.

Hemminga M.A. (1998) The root/rhizome system of seagrasses: an asset and a burden. Journal of Sea Research, 39, 183-196.

Holmer M., Perez M., Duarte C.M. (2003) Benthic primary producers - a neglected environmental problem in Mediterranean maricultures? Marine Pollution Bulletin, 46, 1372-1376.
Lee Long W.J., Coles R.G., McKenzie L.J. (1996) Deepwater seagrasses in Northeastern Australia - How deep? How meaningful? In: Kuo J., Phillips R.C., Walker D.I., Kirkman H. (Eds), Seagrass Biology. Proceedings of an International Workshop, Rottnest Island, Western Australia 25-29 January 1996, The University of Western Australia, Australia: $41-50$.

Lipkin Y. (1979) Quantitative aspects of seagrass communities, particularly those dominated by Halophila stipulacea, in Sinai (Northern Red Sea). Aquatic Botany, 7, 119-128.

Marbà N., Duarte C.M., Cebrián J., Gallegos M.E., Olesen B., Sand-Jensen K. (1996) Growth and population dynamics of Posidonia oceanica on the Spanish Mediterranean coast: elucidating seagrass decline. Marine Ecology Progress Series, 137, 203-213.

Meinesz A., Boudouresque C.F., Lefevre J.R. (1988) A map of the Posidonia oceanica beds of Marina d'Elbu (Corsica, Mediterranean). P.S.Z.N.I.: Marine Ecology, 9, 243-252.

Miller-Myers R., Virnstein R.W. (2000) Development and use of an epiphyte photo-index (EPI) for assessing epiphyte loadings on the seagrass Halodule wrightii. In: Bortone S. (Ed.), Seagrasses: Monitoring, Ecology, Physiology and Management. Proceedings of a Workshop "Subtropical and Tropical Seagrass Management Ecology: Responses to Environmental Stress" held in Fort Myers, Florida (USA) 14-16 October 1998. CRC Press, Boca Raton (Florida), USA, 115-123.

Peirano A., Stoppelli N., Bianchi C.N. (2000) Use of underwater photography for in situ monitoring of fruit development of Posidonia oceanica (L.) Delile. Biologia Marina Mediterranea, 7 (2), 107-110.

Pergent-Martini C., Rico-Raimondino V., Pergent G. (1995) Nutrient impact on Posidonia oceanica seagrass meadows: preliminary data. Marine Life, 5, 3-9.

Procaccini G., Buia M.C., Gambi M.C., Perez M., Pergent G., Pergent-Martini M.C., Romero J. (2003) The seagrasses of the western Mediterranean. In: Green E.P., Short F.T. (Eds), World Atlas of Seagrasses. Prepared by the UNEP World Conservation Monitoring Centre. University of California Press, Berkeley, USA, 48-58.

Sand-Jensen K. (1977) Effect of epiphytes on eelgrass photosynthesis. Aquatic Botany, 3, 55-63.

Silberstein K., Chiffings A.W., McComb A.J. (1986) The loss of seagrass in Cockburn Sound, Western Australia. III. The effect of epiphytes on productivity of Posidonia australis Hook F. Aquatic Botany, 24, 355-371.

Underwood A.J. (1997) Experiments in Ecology: Their Logical Design and Interpretation using Analysis of Variance.

Cambridge University Press, Cambridge. 